\title{
Pelatihan Pemanfaatan Limbah Cangkang Telur sebagai Bahan Baku Pembuatan Kerajinan Kolase pada Keramik Tanah (Gerabah) di Kabupaten Gowa
}

\author{
Ali Ahmad Muhdy ${ }^{1}$, Abd. Aziz Ahmad ${ }^{2}$ \\ 1,2Jurusan Pendidikan Seni Rupa, Fakultas Seni dan Desain, Universitas Negeri Makassar
}

\begin{abstract}
The students of MTs Sultan Hasanuddin Pattunggalengang Limbung, Bajeng Subdistrict, Gowa Regency are the people of the nation, full of potential which is expected to equip themselves to build their independence through various training activities related to the field of study of cultural arts which they have been studying for example art studies. In the information and technology era, students are expected to take part and participate in developing the potential and talents that they have, in order to realize their independence and avoid full dependence on others in the future. One form in filling students' lives while they are still in the learning process is practicing fine arts skills in the form of training in making collage craft from natural waste raw materials in the form of eggshells that are processed in such a way as to become a form of art. The purpose of this activity is to provide knowledge in psychomotor (skills) aspects of expression and creative creation freely through a number of media such as eggshells, glue, pottery, clear (varnish), and brushes. The method used in this training activity is the lecture method, question and answer, demonstration (practice and exhibition), while the presentation is sorted according to the schedule and allocation of time provided. This activity lasts for three working days, starting on Wednesday, September 6-8 2018 in one of the classrooms. To find out and measure the extent of the participants' ability to process and compile various media provided, the instructor evaluates in practical activities. The results of the activity showed that the participants were able to express and be creative in creating interesting motifs according to each section with an average quality of 60-80, the minimum completeness value of the entire work produced.
\end{abstract}

Keywords: eggshells, fine arts skills, training activities

\section{PENDAHULUAN}

Universitas Negeri Makassar merupakan lembaga perguruan tinggi yang memilki visi dan misi sebagai pusat pendidikan, pengkajian, dan pengembangan pendidikan sains, teknologi, dan seni berbasis dan berwawasan kependidikan, kewirausahaan yang menghasilkan sumber daya manusia profesional di bidang kependidikan dan nonkependidikan, sebagai lembaga yang menganut prinsip tridharma perguruan tinggi, penekanannya meliputi aspek pengajaran, penelitian, dan pengabdian, di antara ketiga aspek tersebut maka aspek pengabdianlah yang menjadi sasaran utama dalam kegiatan ini (Gustami, 1991). Penyuluhan dan pelatihan pemanfaatan limbah cangkang telur sebagai bahan baku pembuatan kerajinan kolase pada keramik tanah (gerabah), sebuah tema yang akan penulis angkat kemudian selanjutnya dilaksanakan di depan siswa-siswi Madrasah Tsanawiah Sultan Hasanuddin Pattunggalengang
Kecamatan Bajeng Kabupaten Gowa melalui kerja sama Lembaga Pengabdian kepada Masyarakat (LPM) Universitas Negeri Makassar dengan Yayasan Pendidikan Sultan Hasanuddin.

\section{BAHAN DAN METODE}

Konstruksi bahan yang digunakan sangatlah sederhana dan tidak membuat para peserta kewalahan mengenal dan mencarinya mengingat materi yang dibutuhkan adalah bagian limbahlimbah alam yang lebih akrab dan lebih dekat dengan para peserta (Raharjo, 2011), antara lain:

a. Cangkang telur bebek, ayam, dan puyuh

b. Keramik tanah (gerabah)

c. Lem pox putih

d. Batu koral atau kerikil kecil

e. Cat pilox jenis clear atau pewarna netral

f. Kembang artifisial

Kegiatan pelatihan ini terlaksana dengan menggunakan cara: 
a. Metode ceramah yang diselingi dengan tanya jawab.

b. Metode pelatihan dan bimbingan melalui tuntutan teknik atau cara pembuatan bentukbentuk seni kerajinan kolase dari bahan baku cangkang telur dari peserta ke peserta lain secara bergilir sambil melepaskan proses selanjutnya kepada masing-masing peserta sampai selesai.

c. Metode demonstrasi dan peragaan, dengan memperagakan teknik atau cara pembuatan bentuk seni kerajinan kolase, dan pada kesempatan yang sama peserta diminta mengambil bagian peragaan tadi, sementara peserta lain ikut memperhatikan.

\section{HASIL DAN PEMBAHASAN}

Kegiatan pelatihan pembuatan seni kerajinan kolse dari bahan cangkang telur sebagai bahan baku utama untuk menciptakan kreasi kerajinan (handycraft) bagi siswa-siswi Madrasah Tsanawiah Sultan Hasanuddin Pattunggalengang Gowa dilaksanakan pada Kamis, Jumat, dan Sabtu 06 s.d. 08 September 2018 yang dilaksanakan di Baruga Ahmad Husain milik yayasan pendidikan Sultan Hasanuddin. Kegiatan ini diawali pembukaan oleh kepala sekolah bapak Kamarullah, S.Ag., M.Pd. dan setelah itu dilanjutkan oleh instruktur, yakni Drs. H. Ali Ahmad Muhdy, M.Pd. dan Prof. Dr. H. Abd. Aziz Ahmad, M.Pd. Kedua instruktur berasal dari latar belakang pendidikan seni yang mengabdikan diri pada Fakultas Seni dan Desain Universitas Negeri Makassar.

Setelah pelatihan berlangsung efektif selama kurung waktu satu minggu maka hasil yang dapat dicapai diawali dengan:
a. Persiapan bahan
b. Pengolahan bahan
c. Perancangan
d. Peragaan
e. Sentuhan akhir (finishing)

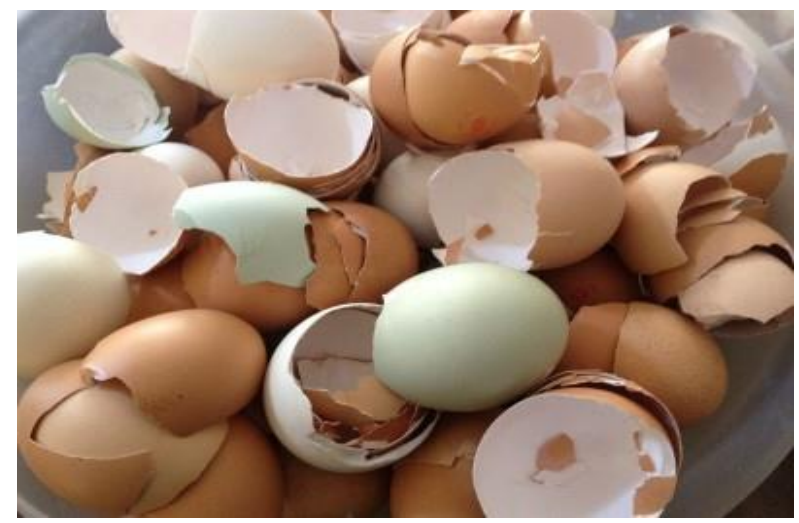

Gambar 1. Bahan dasar cangkang telur

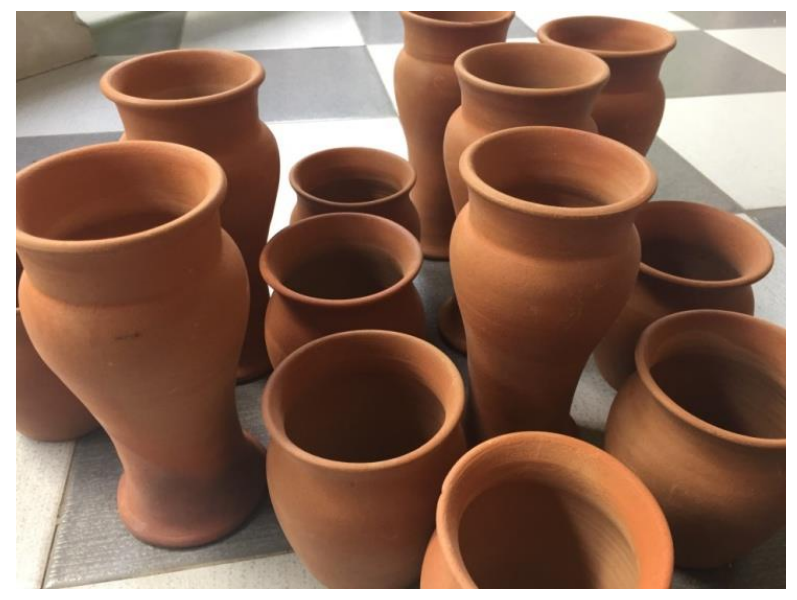

Gambar 2. Bahan dasar keramik tanah (gerabah)

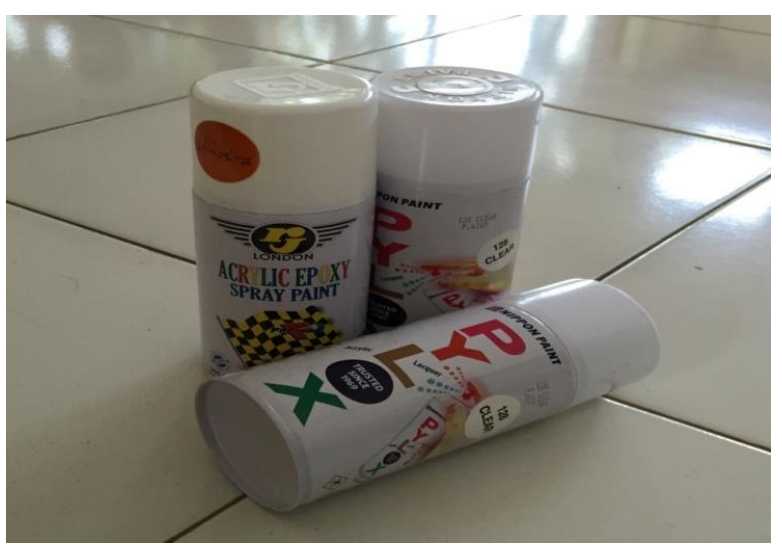

Gambar 3. Bahan glasir clear spray 


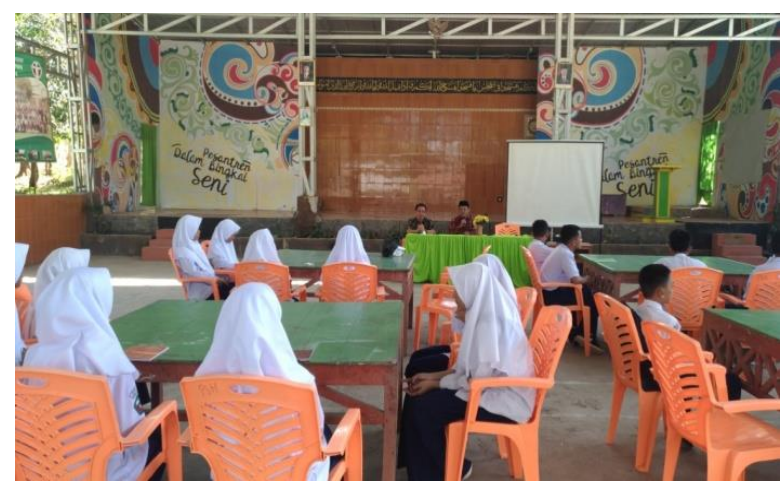

Gambar 4. Pembukaan oleh Kepala Madrasah Tsanawiah

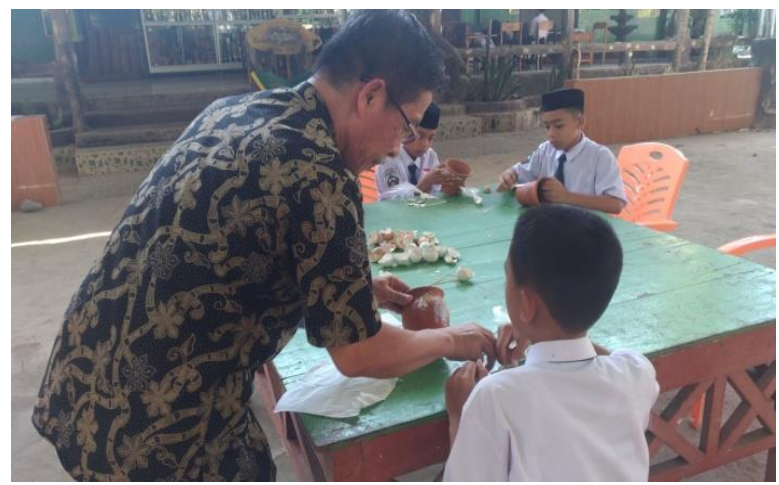

Gambar 5. Proses pelatihan

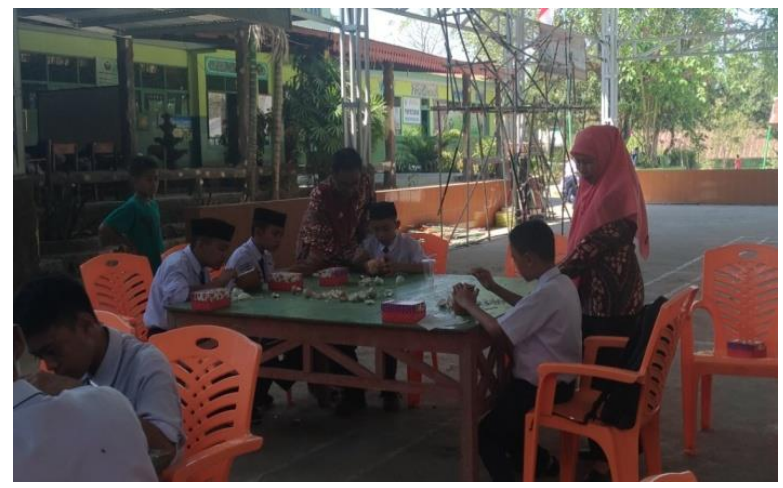

Gambar 6. Pembimbingan/pelatihan

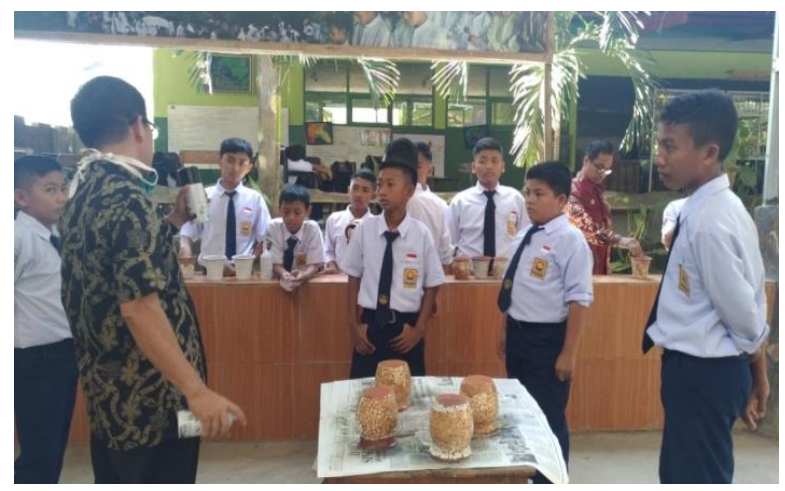

Gambar 7. Proses akhir

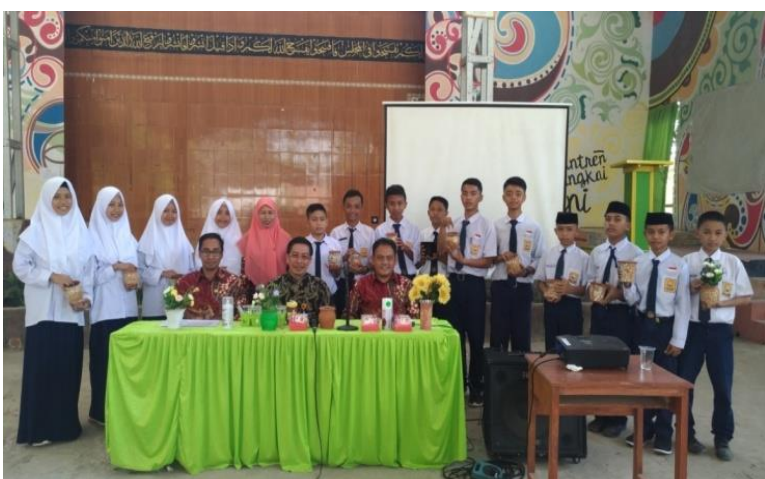

Gambar 7. Foto bersama hasil produk

\section{KESIMPULAN}

Kegiatan pengabdian kepada masyarakat ini terlaksana dengan baik atas kerjasama tim pelaksana dengan Kepala Madrasah Tsanawiah Sultan Hasanuddin Pattunggalengang Gowa. Selain itu adanya dukungan dari Yayasan Pendidikan Sultan Hasanuddin Pattunggalengang Gowa dan Khalayak sasaran para siswa kelas IX MTs.

Peserta pelatihan mempunyai motivasi yang tinggi mengikuti pelatihan mulai awal sampai selesainya pelatihan. Peserta pelatihan berperan aktif dalam kegiatan pelatihan seperti dalam diskusi, Tanya jawab, dan dalam menyelesaikan tugas-tugas yang diberikan selama pelatihan.

Adapun hasil yang diperoleh peserta pelatihan adalah sebagian besar peserta telah memahami apa itu seni kerajinan kolase sebagai elemen rupa, khususnya bentuk-bentuk seni kolase, demikian pula peserta telah memahami prinsip-prinsip seni rupa dan langkah-langkah pembuatan seni kerajinan kolase, dan mereka mampu membuatnya meskipun belum sesempurna yang diinginkan.

\section{UCAPAN TERIMA KASIH}

Kegiatan pelatihan berlangsung dengan tertib dan tercapai sesuai jadwal dan target yang diharapkan berkat dukungan berbagai pihak, oleh karena itu pada momentum ini kedua instruktur menyampaikan terima kasih kepada Prof. Dr. H. Husain Syam, M.TP. Rektor Universitas Negeri Makassar, Prof. Dr. Ir. H. Bakhrani A. Rauf, MT. Ketua Lembaga Pengabdian kepada Masyarakat Universitas Negeri Makassar, Dr. Nurlina Syahrir, 
M.Hum. Dekan Fakultas Seni dan Desain dan pendukung kegiatan pelatihan pembuatan Universitas Negeri Makassar, KH. Bachtiar karya seni kerajinan kolase.

Syamsuddin, Lc., MA. Ketua Yayasan Pendidikan

Sultan Hasanuddin Pattunggalengang Kec.Bajeng

Kab.Gowa, Kamarullah, S.Ag., M.Pd. Kepala Madrasah Tsanawiah Sultan Hasanuddin Pattunggalengang Gowa dan seluruh siswa-siswi peserta

\section{DAFTAR PUSTAKA}

Gustami, SP., 1991. Seni Keriya Indonesia Delema Pembinaan dan Pengembangan dalam Seni. BP. ISI Yogyakarta.

Raharjo, Timbul., Dr., M.Hum., 2011. Seni Keriya dan Kerajinan. Cetakan Pertama, Penerbit PPs ISI Yogyakarta. 